http://dx.doi.org/10.1590/1678-4162-8636

Arq. Bras. Med. Vet. Zootec., v.68, n.4, p.1069-1076, 2016

\title{
Meat characteristics of cattle fed diets containing whole cottonseed
}

[Características da carne de bovinos alimentados com dietas contendo caroço de algodão]

\author{
V.S. Gomes ${ }^{1}$, S.B. Mano ${ }^{1}$, M.Q. Freitas ${ }^{1}$, M.D.Santos ${ }^{2}$, C.A. Conte Júnior ${ }^{1}$ \\ J.M. Silva ${ }^{2}$, E.B. Santos ${ }^{1}$ \\ ${ }^{1}$ Universidade Federal Fluminense - Niterói, RJ \\ ${ }^{2}$ Universidade de Cuiabá - Cuiabá, MT
}

\begin{abstract}
Sensory and instrumental analyses evaluated the meat and fat characteristics of feedlot-finished steers fed a diet containing cottonseed. Global impression, texture, meat color, and fat color were assessed. Thirty Nellore bulls with an average age of $30 \pm 6$ months and initial body weight of $382.7 \pm 28.4 \mathrm{~kg}$ were kept in feedlot stalls and fed the following cottonseed levels: $0 ; 2.22 \% ; 4.44 \% ; 6.66 \% ; 8.88 \% ; 11.11 \%$ of the dietary dry matter. The cottonseed used in this experiment had an average free gossypol content of $4.5 \mathrm{~g} / \mathrm{kg}$ of cottonseed. The overall impression of the samples, assessed by the triangle test for difference, did not differ for more than $62 \%$ of the panelists $(\mathrm{P}>0.01)$. The shear strength of roasted meat varied from 6.00 to $6.54 \mathrm{~kg}$. According to texture profile analysis (TPA), the hardness, springiness, and chewiness of roast meat ranged from 24.15 to $28.01 \mathrm{~N}, 0.52$ to $0.56,8.42$ to $11.01 \mathrm{~N}$, respectively; of raw meat, 9.51 to $13.86 \mathrm{~N}, 0.26$ to 0.29 , and 1.38 to $1.81 \mathrm{~N}$, respectively. The different treatments did not affect meat texture, meat color, or fat color $(\mathrm{P}>0.05)$. Meat color, luminosity, and red intensity ranged from 37.71 to $42.85,20.68$ to 25.25 , and 6.74 to 8.61 , respectively; fat color, luminosity, and yellow intensity ranged from 62.26 to $63.78,11.13$ to 11.62 , and 10.53 to 10.86 , respectively. Cottonseed intake of up to $1.13 \mathrm{~kg} / \mathrm{animal} / \mathrm{day}$, equivalent to a free gossypol intake of $5.05 \mathrm{~g} / \mathrm{animal} / \mathrm{day}$, in place of soybean meal and ground corn, did not significantly change the global sensory impression, texture, and color of the meat and fat.
\end{abstract}

Keywords: meat, texture, gossypol, whole cottonseed

\section{RESUMO}

Avaliou-se, por meio de análise sensorial e instrumental, o efeito da adição de caroço de algodão à dieta de bovinos confinados sobre as características da carne e da gordura. Foram avaliadas a impressão global, a textura, a cor da carne e a cor da gordura. Trinta touros da raça Nelore, com médias de idade e peso vivo inicial de $30 \pm 6$ meses e 382,7 $\pm 28,4 \mathrm{~kg}$, foram confinados e receberam dietas com os seguintes teores de caroço de algodão: 0; 2,22\%; 4,44\%; 6,66\%; 8,88\%; 11,11\% na matéria seca da dieta. O caroço de algodão utilizado neste experimento apresentou conteúdo médio de $4,5 \mathrm{~g}$ de gossipol livre/kg de caroço de algodão. A impressão global da carne, avaliada por meio de teste triangular de diferença, mostrou que mais de $62 \%$ dos provadores não perceberam diferença significativa $(P>0,01)$ entre as amostras. A textura da carne assada avaliada por meio do teste de força de cisalhamento variou de 6,00 a 6,54kg. Na análise do perfil de textura (TPA) da carne assada, a dureza, a elasticidade e a mastigabilidade variaram, respectivamente, de 24,15 a $28,01 N$, de 0,52 a 0,56N e de 8,42 a 11,01N. Na TPA da carne crua, variaram, respectivamente, de 9,51 a 13,86N, de 0,26 a 0,29N e de 1,38 a 1,81N. Na avaliação da cor da carne, a luminosidade, a intensidade de vermelho e a intensidade de amarelo da cor da carne variaram, respectivamente, de 37,71 a 42,85, de 20,68 a 25,25 e de 6,74 a 8,61. E para a cor da gordura, variaram, respectivamente, de 62,26 a 63,78, de 11,13 a 11,62 e de 10,53 a 10,86. A textura, a cor da carne e a cor da gordura não apresentaram diferenças significativas $(P>0,05)$ entre os diferentes tratamentos. O consumo de caroço de algodão em até $1,13 \mathrm{~kg} /$ animal/dia, que resultou no consumo de $5,05 \mathrm{~g}$ de gossipol livre/animal/dia, em substituição ao farelo de soja e ao grão de milho triturado, não causou alterações significativas nas características da carne quanto à impressão sensorial global, à textura, à cor da carne e à cor da gordura.

Palavras-chave: carne, textura, gossipol, caroço de algodão

Recebido em 31 de julho de 2015

Aceito em 15 de fevereiro de 2016

E-mail: vivinutri_gomes@yahoo.com.br 


\section{INTRODUCTION}

Brazil holds a prominent position in the global beef market. About $80 \%$ of the herds consist of animals of Zebu breeds (Bos indicus), which are animals of proven hardiness and adaptation to the prevailing environment in Brazil. Among these breeds, we can highlight the Nellore, with $90 \%$ of the whole (Rebanho..., 2015).

Ruminants are raised in Brazil on natural or cultivated pastures, but pasture production is not steady throughout the year. In addition the advance of agriculture on pasture and the rising cost of land create a need of higher yield per acre. In this context, cattle feedlot is an alternative because it adds value to the final product by supplying animals for slaughter offseason with desirable carcass characteristics, such as good appearance and tender meat. However, feedlot costs are high (Costa et al., 2011).

Diets with alternative foods, such as agroindustrial residues, have been created in an attempt to reduce feeding costs (Nunes et al., 2007). Cottonseed is an excellent option for feedlot cattle because of its high protein, fiber, and energy contents (Bertrand et al., 2005), but its use has limitations. One such limitation is the presence of gossypol, a toxic polyphenol that occurs naturally in the pigment glands of cottonseeds. Additionally, this reactive compound rapidly binds to minerals and amino acids when it is in its free form (Guedes and Soto-Blanco, 2010). Factors that predispose ruminants to gossypol poisoning are: age, duration of intake, rumen function, and protein and mineral contents of the feed. Gossypol is cumulative, so poisoning tends to occur after several weeks or months of intake (Rogério et al., 2003).

Another limitation for the use of cottonseed is its unsaturated fatty acid content. The high energy content of this oilseed can change ruminal fermentation by suppressing bacterial cellulolytic and methanogenic activity (Van Soest, 1994). Problems in beef flavor have been associated with the use of cottonseed (Costa et al., 2013). Given that cottonseed diets may compromise meat quality, it is critical to determine feed cottonseed and gossypol contents that will not change meat characteristics.

In face of the above, this study aimed to evaluate the effect of different levels of dietary cottonseed on the meat and fat characteristics of feedlotfinished Nellore cattle.

\section{MATERIAL AND METHODS}

This study was conducted from August to November, 2011. The climate of the experimental area is classified as tropical with dry winter (Aw) (Köppen, 1938). The Research Ethics Committee of the University of Cuiabá $\mathrm{CEP} / \mathrm{UNIC}$ approved the study under registration No. 60 CEP/UNIC - Protocol 2010-061.

Thirty Nellore bulls with an average age of $30 \pm 6$ months and body weight of $382.7 \pm 28.4 \mathrm{~kg}$ were used for the feedlot operation, which lasted 85 days. The animals were identified, vaccinated, and subjected to parasite control before the experimental period.

The mean content of free gossypol in the cottonseed study was determined by highperformance liquid chromatography using the methodology described by Romero et al. (2011). The samples had a mean free gossypol content of $4.5 \mathrm{~g} / \mathrm{kg}$ of cottonseed. The animals would need to consume a mean of $20.4 \mathrm{~kg} / \mathrm{animal} /$ day of organic matter intake (OMI) to keep the mean free gossypol content in different treatments between 0 and $5 \mathrm{~g}$ of free gossypol/animal/day (Table 1).

The bulls were randomly distributed into six feedlot stalls with an area of $100 \mathrm{~m} 2$ each, containing a feed bunker and drinker. The five animals in each stall received diets with increasing amounts of whole cottonseed as follows: $0 ; 2.22 ; 4.44 ; 6.66 ; 8.88$; and $11.11 \mathrm{~kg} / 100 \mathrm{~kg}$ of dry matter (DM) (Tab. 2). The diets were formulated according to the requirements of bulls growing at a rate of $1.2 \mathrm{~kg} /$ animal $/$ day. All diets had the same energy and nitrogen contents as established by Valadares Filho et al. (2006). The animals were fed three times a day, at $07 \mathrm{~h} 00,12 \mathrm{~h} 00$, and $17 \mathrm{~h} 00$. 
Table 1. Bovine mean intake of whole cottonseed (CWI) and free gossypol (FGI) during the experimental period by treatment

\begin{tabular}{lcccccc}
\multirow{2}{*}{ Item } & \multicolumn{7}{c}{ Whole cottonseed (\%) } \\
\cline { 2 - 7 } & 0 & 2.22 & 4.44 & 6.66 & 8.88 & 11.11 \\
\hline CWI (kg/animal/day) & - & 0.22 & 0.45 & 0.66 & 0.89 & 1.11 \\
FGI (g/animal/day) & - & 1.00 & 2.00 & 3.00 & 4.00 & 5.00 \\
\hline
\end{tabular}

Table 2. Proportion of the ingredients of the experimental diets based on dry matter and bromatological composition

\begin{tabular}{lcccccc}
\hline \multirow{2}{*}{ Ingredients (\%)* } & \multicolumn{7}{c}{ Whole cottonseed (\%) } \\
\cline { 2 - 7 } & 0 & 2.22 & 4.44 & 6.66 & 8.88 & 11.11 \\
\hline Corn silage & 50.00 & 50.00 & 50.00 & 50.00 & 50.00 & 50.00 \\
Whole cottonseed & 0.00 & 2.22 & 4.44 & 6.66 & 8.88 & 11.11 \\
Ground corn & 40.46 & 39.06 & 39.63 & 36.22 & 34.8 & 33.39 \\
Soybean meal & 8.54 & 7.72 & 6.93 & 6.12 & 5.32 & 4.50 \\
Mineral mixture** & 1.00 & 1.00 & 1.00 & 1.00 & 1.00 & 1.00 \\
\hline Crude protein $^{(1)}$ & 11.00 & 11.00 & 11.00 & 11.00 & 11.00 & 11.00 \\
Ether extract $^{(1)}$ & 3.25 & 3.60 & 3.95 & 4.30 & 4.65 & 5.00 \\
Neutral detergent fiber $^{(2)}$ & 34.61 & 35.26 & 35.9 & 35.55 & 37.2 & 37.85 \\
Total digestible nutrients $^{(3)}$ & 71.20 & 71.10 & 71.10 & 71.07 & 71.03 & 71.00
\end{tabular}

*2.5g of Rumensin ${ }^{\circledR}$ per animal/day and approximately $90 \mathrm{~g} \mathrm{NaCl}$ per animal/day were added to the diets.

$* *$ sodium chloride $=27.02 \%$; dicalcium phosphate $=67.30 \%$; manganese sulfate $=1.28 \%$, zinc sulfate $=3.67 \%$, copper sulfate $=0.67 \%$, cobalt sulfate $=0.04 \%$; sodium selenite $=0.003 \%$ and potassium iodate $=0.002 \%$.

${ }^{1}$ Determined by the method described by Silva and Queiroz (2002)

${ }^{2}$ Determined by the method described by Van Soest et al. (1991)

${ }^{3}$ Values estimated according to Capelle et al. (2001).

The leftovers in the troughs were weighed daily to determine intake. Diet and leftover samples from each treatment were collected daily and combined weekly to compose a representative weekly sample for future analysis. These samples were then frozen to $-18^{\circ} \mathrm{C}$ and used for determining the DM content of the different treatments. The mean daily organic matter intake (OMI), whole cottonseed intake (CWI), and gossypol intake (FGI) of animals in the different treatments were calculated at the end of the experiment.

The bulls were weighed after 12 hours of solids fasting at the beginning of the experiment and after 85 days of feedlot to evaluate the effect of the diets on weight gain. The animals were slaughtered after a fasting period of 24 hours at a federally inspected slaughterhouse following the normal slaughter flow. The carcasses were divided longitudinally into two halves. The sirloin (Longissimus dorsi muscle) was taken from the left half-carcass of each animal, chilled to $7^{\circ} \mathrm{C}$ for $24 \mathrm{~h}$, packed in plastic bags, identified, and stored in a freezer at $-18^{\circ} \mathrm{C}$. Three approximately $2 \mathrm{~kg}$ units of these sirloin steaks were chosen randomly from each treatment for sensory, physical, and chemical analyses.

Three sirloin cuts of three animals of each treatment were submitted to sensory analysis, including global impression, instrumental texture, and colorimetry. Cross-sectional samples $2.5 \mathrm{~cm}$ thick from the central part of these cuts were obtained with a chainsaw and allowed to thaw in a refrigerator at $4^{\circ} \mathrm{C}$ for 24 hours.

Roast and raw meat samples were tested. Roast meat was prepared by thawing as described above, wrapping in aluminum foil, and roasting in an electric oven at $230^{\circ} \mathrm{C}$ for about 30 minutes, until the geometric center reached a temperature of roughly $71^{\circ} \mathrm{C}$. Roast meat was submitted to the triangular test for difference, texture profile analysis (TPA), and shear force test (WB). 
The triangle test for difference assessed whether the control treatment (whole cottonseed-free diet) differed from the treatments containing $6.66,8.88$, and $11.11 \mathrm{~kg}$ of whole cottonseed $/ 100 \mathrm{~kg}$ of dry matter. The tests were conducted by 12 trained panelists from Universidade Federal Fluminense, 6 men and 6 women, and 100 untrained panelists, 41 men and 59 women. The trained panelists had to attend at least three of five sessions before sensory analysis to become familiar with the samples from the different treatments. For the test, the roasted samples were cut into cubes of similar size and presented to the panelists in disposable $50 \mathrm{ml}$ plastic cups, along with a questionnaire, and the information that two samples were similar and one was different. The panelists used water and unflavored crackers to cleanse the palate between assessments. Then, they were asked to taste the samples from left to right and identify the one with the different global impression. The three samples were presented in random and balanced order, and always contained the control beef. The number of correct answers required for establishing significant differences can be found in the significance table of the triangle test, using the chi-square test at a probability of $5 \%$ (Manual..., 1968).

To determine whether different levels of dietary whole cottonseed $(0,2.22,4.44,6.66,8.88$ and $11.11 \mathrm{~kg} / 100 \mathrm{~kg}$ ) affect meat texture, analysis of shear force (WB) of roast meat and texture profile analysis (TPA) of raw and roast meat were performed by the texture analyzer TA.XT.Plus, Stable Micro Systems (UK) with a cylindrical probe of $10 \mathrm{~mm}$ diameter (TPA) and Warner-Bratzler blade (WB). The parameters used for these analyses have been described by Ruiz de Huidobro et al. (2005). TPA assessed hardness, springiness, and chewiness. These tests were performed on three horizontal $2.5 \mathrm{~cm}$ samples of each treatment, which were roasted as described above, kept at room temperature for $30 \mathrm{~min}$, and then kept in a refrigerator at $4{ }^{\circ} \mathrm{C}$ for one hour. A manual cutter removed three cylindrical samples of $1.7 \mathrm{~cm}$ diameter of each cross-section. These samples were evaluated with the muscle fibers almost parallel to the direction of force, as typically occurs during chewing (Ruiz de Huidobro et al., 2005).
The color intensities of the meat and fat of the cattle submitted to diets with different levels of whole cottonseed $(0 ; 2.22 ; 4.44 ; 6.66 ; 8.88$ and $11.11 \mathrm{~kg} / 100 \mathrm{~kg}$ ) were determined by colorimetry using color intensities distinguishable by humans. The test was performed on a $2.5 \mathrm{~cm}$ cross-sectional sample of each animal, which was thawed in a refrigerator at $4^{\circ} \mathrm{C}$ for $24 \mathrm{~h}$ and exposed to air for 30 minutes. Three readings were done at different points of the sample surfaces with a Chroma Meter CR-410 meter (Konica Minolta). The study parameters were luminosity $\left(\mathrm{L}^{*}\right)$, red intensity $\left(\mathrm{a}^{*}\right)$, and yellow intensity ( $\left.b^{*}\right)$ (CIELab system).

The experiment design was completely randomized, with four treatments and three repetitions for sensory testing; and with six treatments and three repetitions for texture and color intensity analysis. The study variables were subjected to analysis of variance using the statistics software for Windows XLSTAT version 2015.1.03. The means were compared by the Tukey test at a probability of $5 \%$.

\section{RESULTS AND DISCUSSION}

Table 3 describes the experimental diets with their organic matter (OMI), whole cottonseed (CWI), and free gossypol contents (FGI). The intakes of free gossypol, ranging from $1.08 \mathrm{~g} / \mathrm{animal} /$ day to $5.05 \mathrm{~g} / \mathrm{animal} / \mathrm{day}$, did not affect the animals' health and performance. The diets' high protein content helped to reduce the risk of gossypol poisoning because gossypol rapidly binds to minerals and amino acids when it is in its free form (Guedes and Soto-Blanco, 2010). Other factors that predispose ruminants to gossypol poisoning are: age, duration of intake, rumen function, and protein and mineral content of the feed. Given its cumulative nature, gossypol needs to be consumed for several weeks or months before poisoning signs appear (Rogério et al., 2003).

Daily weight gain, final body weight, and dry matter intake did not differ between treatments $(\mathrm{P}>0.05)$. Although total weight gain was higher in the control group, the difference was not significant $(\mathrm{P}>0.05)$ (Table 4$)$. 
Table 3. Mean contents of organic matter (OMI), whole cottonseed (CWI), and free gossypol (FGI) in diets with different levels of whole cottonseed consumed by bulls for 85 days

\begin{tabular}{lcccccc}
\multirow{2}{*}{ Item } & \multicolumn{7}{c}{ Whole cottonseed (\%) } \\
\cline { 2 - 7 } & 0 & 2.22 & 4.44 & 6.66 & 8.88 & 11.11 \\
\hline OMI (kg/animal/day) & 22.0 & 22.1 & 20.9 & 22.4 & 19.4 & 20.7 \\
CWI (kg/animal/day) & - & 0.24 & 0.46 & 0.72 & 0.85 & 1.13 \\
FGI (g/animal/day) & - & 1.08 & 2.07 & 3.26 & 3.81 & 5.05 \\
\hline
\end{tabular}

${ }^{1}$ Intake estimate based on the OMI and percentage of whole cottonseed added to the diets. ${ }^{2}$ Intake estimate based on the CWI, considering the mean content of free gossypol in the study whole cottonseed ( $4.5 \mathrm{~g}$ of free gossypol $/ \mathrm{kg}$ of whole cottonseed).

Table 4. Means and standard deviation of the bulls' performance characteristics by treatment during the 85-day experimental period

\begin{tabular}{|c|c|c|c|c|c|c|c|}
\hline \multirow{2}{*}{ Characteristics } & \multicolumn{6}{|c|}{ Whole cottonseed (\%) } & \multirow{2}{*}{$\begin{array}{l}\text { Standard } \\
\text { deviation }\end{array}$} \\
\hline & 0 & 2.22 & 4.44 & 6.66 & 8.88 & 11.11 & \\
\hline Initial body weight $(\mathrm{kg})$ & 378.7 & 384.0 & 384.0 & 384.0 & 380.0 & 384.0 & 2.44 \\
\hline Final live weight $(\mathrm{kg})$ & 555.2 & 540.0 & 544.0 & 548.6 & 523.7 & 531.0 & 11.55 \\
\hline Daily weight gain* & 2.07 & 1.83 & 1.88 & 1.93 & 1.69 & 1.73 & 0.14 \\
\hline Consumption of dry matter* & 22.0 & 22.1 & 20.9 & 22.4 & 19.4 & 20.7 & 1.14 \\
\hline Total weight gain* & 176.5 & 156.0 & 160.0 & 164.6 & 143.7 & 147.0 & 11.99 \\
\hline
\end{tabular}

$* \mathrm{~kg} / \mathrm{animal} / \mathrm{day}$

According to the trained and untrained panelists, whole cottonseed until the maximum level of $11.11 \mathrm{~kg} / 100 \mathrm{~kg}$ of diet did not change the global impression of the meat assessed by the triangle test for difference $(\mathrm{P}>0.01)$ (Table 5). This result corroborates Pesce (2008), who studied whole cottonseed influence on meat attributes and did not find changes in the flavor or aroma of meat from cattle fed diets containing as much as $20 \%$ whole cottonseed. Costa et al. (2013) reported that meat aroma and flavor are negatively affected by whole cottonseed contents above 27.51 and $34.09 \mathrm{~kg} / 100 \mathrm{~kg}$ of diet, respectively.

Table 5. Global impression of meat from cattle fed different levels of dietary whole cottonseed according to trained and untrained panelists using the triangle test for difference

\begin{tabular}{lcc}
\hline \multirow{2}{*}{ Levels of whole cottonseed (\%) } & \multicolumn{2}{c}{ Number of responses in Triangle Difference } \\
\cline { 2 - 3 } & Tests \\
\hline Trained panelists (12) & 11 & Right \\
$11.11 \%$ & 8 & 1 \\
$8.88 \%$ & 9 & 4 \\
$6.66 \%$ & & 3 \\
Untrained panelists (100) & 62 & 38 \\
$11.11 \%$ & 67 & 33 \\
$8.88 \%$ & 64 & 36 \\
$6.66 \%$ & & \\
\hline
\end{tabular}

The shear force (WB) of roast meat ranged from $6 \mathrm{~kg}$ to $6.54 \mathrm{~kg}$. Table 6 shows the texture profile analysis (TPA) of raw and roasted meat. The shear force and TPA did not differ by treatment (P>0.05). Similarly, Costa et al. (2013) did not find shear force differences in meat samples of cattle fed diets with different whole cottonseed levels. The main advantage of TPA is the ability of assessing many variates with a double compression cycle. High shear force is a characteristic of Bos taurus indicus (Shackelford et al., 1994) cattle, and increasing participation of zebu genes (Bos taurus indicus) in the genotype hardens the meat (Sherbeck et al., 1996). However, other factors also influence texture, such as feedlot time and feed composition (Costa et al., 2013). However, the study meat texture did not differ in either test. 
Table 6. Values for the instrumental texture parameters of raw and roast meat

\begin{tabular}{|c|c|c|c|c|c|c|c|c|}
\hline \multirow{2}{*}{$\begin{array}{l}\text { Parameters } \\
\text { Instrumental }\end{array}$} & \multicolumn{6}{|c|}{ Cottonseed in diet $(\mathrm{kg} / 100 \mathrm{~kg})$} & \multirow{2}{*}{$\begin{array}{l}\text { Standard } \\
\text { deviation }\end{array}$} & \multirow{2}{*}{$\operatorname{Pr}>F$} \\
\hline & 0 & 2.22 & 4.44 & 6.66 & 8.88 & 11.11 & & \\
\hline \multicolumn{9}{|l|}{ Roast meat } \\
\hline Shear force WB (kg) & 6.54 & 6.12 & 6.45 & 6.49 & 6.40 & 6.00 & 0.45 & 0.04 \\
\hline Hardness TPA (N) & 24.98 & 27.12 & 25.88 & 25.07 & 28.01 & 24.15 & 2.98 & 0.21 \\
\hline Springiness TPA & 0.52 & 0.55 & 0.55 & 0.55 & 0.56 & 0.55 & 0.03 & 0.24 \\
\hline Chewiness TPA (N) & 8.42 & 11.01 & 9.19 & 9.31 & 10.93 & 9.52 & 1.83 & 0.08 \\
\hline \multicolumn{9}{|l|}{ Raw meat } \\
\hline Hardness TPA (N) & 12.35 & 11.95 & 12.29 & 13.86 & 12.78 & 9.51 & 3.44 & 0.16 \\
\hline Springiness TPA & 0.29 & 0.27 & 0.26 & 0.28 & 0.29 & 0.27 & 0.02 & 0.28 \\
\hline Chewiness TPA (N) & 1.38 & 1.56 & 1.55 & 1.68 & 1.81 & 1.44 & 0.40 & 0.23 \\
\hline
\end{tabular}

TPA: Texture profile analysis; WB: Warner-Bratzler shear test

Luminosity ( $\mathrm{L}^{*}$ ) ranged from 37.71 to 42.85 ; red intensity ranged from 20.68 to 25.25 ; and yellow intensity ranged from 6.74 to 8.61 (Table 7). Mean $\mathrm{L}^{*}$ was 39.64 , which is similar to the means reported by Rodrigues and Andrade (2004) and Costa et al. (2008). Whole cottonseed did not affect luminosity, red intensity, and yellow intensity $(\mathrm{P}>0.05)$. More marbling may be associated with a higher yellow intensity $\left(\mathrm{a}^{*}\right)$ than that found by Costa et al. (2013). Color is one of the major meat attributes that best reflects the amount and chemical state of meat's main pigment, myoglobin. Older and highly active animals have darker meat (Felício, 1999). Therefore, young bulls have darker meat than male and female calves (Purchas et al., 1990). Color intensity similarity between the different treatments may be related to the similar ages of the animals and same feedlot regimen.

Table 7. Meat and fat color intensities of Nellore bulls by whole cottonseed intake

\begin{tabular}{lccccccccc}
\multirow{2}{*}{ Item } & \multicolumn{7}{c}{ Cottonseed in diet $(\mathrm{kg} / 100 \mathrm{~kg})$} & \multirow{2}{*}{$\begin{array}{c}\text { Standard } \\
\text { deviation }\end{array}$} & \multirow{2}{*}{$\operatorname{Pr}>\mathrm{F}$} \\
\cline { 2 - 8 } & 0 & 2.22 & 4.44 & 6.66 & 8.88 & 11.11 & & \\
Meat color & & & & & & & & & \\
Luminosity & 38.88 & 37.71 & 42.85 & 39.23 & 39.92 & 39.23 & 2.25 & 0.08 \\
Red intensity & 25.25 & 22.71 & 24.80 & 20.68 & 22.14 & 24.90 & 3.09 & 0.40 \\
Yellow intensity & 7.73 & 6.74 & 8.53 & 6.74 & 7.72 & 8.61 & 1.90 & 0.79 \\
\hline Fat color & & & & & & & & \\
Luminosity & 62.26 & 62.78 & 62.64 & 62.77 & 63.29 & 63.78 & 0.86 & 0.17 \\
Red intensity & 11.42 & 11.52 & 11.32 & 11.13 & 11.62 & 11.38 & 0.25 & 0.26 \\
Yellow intensity & 10.86 & 10.53 & 10.86 & 10.72 & 10.83 & 10.84 & 0.18 & 0.18 \\
\hline
\end{tabular}

Fat from different treatments had similar luminosity, red intensity, and yellow intensity $(\mathrm{P}>0.05)$. Cattle fat color depends on age, gender, and breed. Diet is more extrinsic, but it depends on feed time (Dunne et al., 2009). The variation in cattle fat color results from carotenoid accumulation, which makes fat yellowish (Felício, 1999). Pasture-raised cattle generally have darker yellow fat than animals raised in intensive systems with high levels of concentrate because of forage carotenoids (Dunne et al., 2009). Although fat color is not associated with nutritional problems, consumers usually reject yellow fat, preferring white fat, since yellow intensity is usually associated with older animals (Felício, 1999). The appearance of cattle fat is mainly affected by the accumulation of carotene and hemoglobin derivatives, and fat reflectance, transmittance, fluorescence, reflectance, and fluorescence of non-lipid components, such as connective tissue and cell membranes (Irie, 2001). The similar rearing system and cattle ages may explain why fat luminosity, red intensity, and yellow intensity did not differ between treatments. The luminosity results are similar to those reported by Costa et al. (2013). 


\section{CONCLUSIONS}

The intake of $1.13 \mathrm{~kg}$ of cottonseed/animal/day, which resulted in an intake of $5.05 \mathrm{~g}$ of free gossypol/animal/day, replacing soybean meal and ground corn, did not change the global sensory impression and texture of the meat, meat color, or fat color.

\section{REFERENCES}

BERTRAND, J.A.; SUDDUTH, T.Q.; CONDON, A. et al. Nutrient content of whole cottonseed. J. Dairy Sci., v.88, p.1470-1477, 2005 .

CAPELLE, E.R.; COELHO SILVA, J.F.; VALADARES FILHO, S.C. Estimativas do valor energético a partir de características químicas e bromatológicas dos alimentos. Rev. Bras. Zootec., v.6, p.1837-1856, 2001.

COSTA, D.P.B.; ROÇA, R.O.; COSTA, Q.P.B. et al., W.M. Meat characteristics of Nellore steers fed whole cottonseed. Rev. Bras. Zootec., v.42, p.183-192, 2013.

COSTA, D.P.B.; RODRIGUES, V.C.; SILVA J.C.G. et al. Qualidade da carne de novilhos Nelore e $F_{1}$ Nelore x Sindi. Arch. Zootec., v.57, p.345-348, 2008.

COSTA, Q.P.B.; WECHSLER, F.S.; COSTA, D.P.B. et al. Desempenho e características da carcaça de bovinos alimentados com dietas com caroço de algodão. Arq. Bras. Med. Vet. Zootec., v.63, p.729-735, 2011.

DUNNE, P.G.; MONAHAN, F.J.; O'MARA, F.P. et al. Colour of bovine subcutaneous adipose tissue: a review of contributory factors, associations with carcass and meat quality and its potential utility in authentication of dietary history. Meat Sci., v.81, p.28-45, 2009.

FELÍCIO, P.E. Qualidade da carne bovina: características físicas e organolépticas. In: REUNIÃO ANUAL DA SOCIEDADE BRASILEIRA DE ZOOTECNIA, 36., 1999, Porto Alegre. Anais... Porto Alegre: Sociedade Brasileira de Zootecnia, 1999. p.89-97.

GUEDES, F.C.B.; SOTO-BLANCO, B. Sperm quality of sheep fed cottonseed cake. Acta Scien. Vet., v.38, p.415-418, 2010.
IRIE, M. Optical evaluation of factors affecting appearance of bovine fat. Meat Sci., v.57, p.1922,2001 .

KÖPPEN, W. Das geographic system der climate: handbuch der klimatologie. Berlim: Bortraeger, 1938. p.1-44.

MANUAL on sensory testing methods. New York: ASTM, 1968. 77p.

NUNES, H.; ZANINE, A.M.; MACHADO, T.M.M. et al. Alimentos alternativos na dieta dos ovinos: uma revisão. Arch. Latinoam. Prod. Anim., v.15, p.147-158, 2007.

PESCE, D.M.C. Efeito da dieta contendo caroço de algodão no desempenho, características quantitativas da carcaça e qualitativas da carne de novilhos Nelore confinados. 2008. 155f. Tese (Doutorado em Zootecnia) - Faculdade de Zootecnia e Engenharia de Alimentos, Universidade de São Paulo, Pirassununga, SP.

PURCHAS, R.W. An assesment of the role or $\mathrm{pH}$ differences in determining the relative tenderness of meat from bulls and steers. Meat Sci. v.27, p.129-140, 1990.

REBANHO bovino brasileiro. São Paulo: ABIEC, 2015. Disponível em: $<$ http://www.abiec.com.br/3_rebanho.asp $>$. Acessado em: 09/04/2015.

RODRIGUES, V.C.; ANDRADE, I.F. Características físico-químicas da carne de bubalinos e de bovinos castrados e inteiros. Rev. Bras. Zootec., v.33, p.1839-1849, 2004.

ROGÉRIO, M.C.P.; BORGES, I.; SANTIAGO, G.S.; TEIXEIRA, D.A.B. Uso do caroço de algodão na alimentação de ruminantes. Arq. Ciênc. Vet. Zool., v.6, p.85-90, 2003.

ROMERO, A.C.; ULIANA, R.; MARIANO, I.C. et at. Implicações para exatidão na quantificação do gossipol livre: I. Análise da variabilidade intrínseca à matriz. Rev. Educ. Cont. Vet. Med., v.9, p.70-71, 2011.

RUIZ DE HUIDORO, F.; MIGUEL, E.; BLÁZQUEZ, E.; ONEGA, E. A comparison between two methods (Warner-bratzler and texture profile analysis) for testing either raw meat or cooked meat. Meat Sci., v.69, p.527-536, 2005. 
SHACKELFORD， S.D.; KOOHMARIE， M.; CUNDIFF, L.V. et al. Heritabilities and phenotypic and genetic correlations for bovine postrigor calpastatin activity, intramuscular fat content, Warner-bratzler shear force, retail product yield, and growth rate. J. Anim. Sci., v.72, p.857-863, 1994.

SHERBECK, J.A.; TATUM, J.D.; FIELD, T.G. et al. Effect of phenotypic expression of Brahman breeding on marbling and tenderness traits. J. Anim. Sci., v.74, p.304-309, 1996.

SILVA, D.J.; QUEIROZ, A.C. Análise de alimentos: métodos químicos e biológicos. 3.ed. Viçosa, MG: UFV, 2002. 235p.
VALADARES FILHO, S.C.; MAGALHÃES, K.A.; ROCHA JÚNIOR, V.R. et al. Tabelas brasileiras de composição de alimentos para bovinos. 2.ed. Viçosa, MG: UFV, 2006. 329p.

VAN SOEST, P.J. Nutritional ecology of the ruminante. 2.ed. Ithaca: Cornell University, 1994. 528p.

VAN SOEST, P.J.; ROBERTSON, J.B.; LEWIS, B.A. Methods for dietary fiber, Neutral detergent fiber, and nonstarch polysaccharides in relation to animal nutrition. J. Dairy Sci., v.74, p.3583$3597,1991$. 